\title{
Economic Contribution of Cart Horses to the Livelihoods of Families in Gondar Town Ethiopia
}

\author{
Hamelmal Asfaw and Gebrehiwot Tadesse* \\ College of Veterinary Medicine, P. O. box 3183, Mekelle University, Mekelle, Tigray, Ethiopia \\ (*gebrehiwot.tadesse@mu.edu.et).
}

\begin{abstract}
Equines are providing traction power and transport services, like pulling cart, packing and riding, at low cost in both rural and urban areas of Ethiopia. A cross-sectional study was conducted in Gondar city from November 2014 to April 2015 to assess major health problems and to investigate the economic contribution of cart horses to livelihood of the community. Cart horses were randomly selected from the study area. Observational study was also conducted and semistructured questionnaire survey was administered to all cart horse owners. The study revealed that behavioral responses, skin coat and dental conditions were significantly associated with body condition and age of cart horses $(\mathrm{p}<0.05)$. Wound and musculoskeletal problem had no significant association with body condition and age of working horses. Young horses with good body conditions were more prone to wounds $(75 \%)$ than the older horses with poor body conditions. The majority of the carthorse owners used their horses for transportation for long hours (> 8 hours) per a day, 5-6 days per week and loaded them 500-700 kg. The income in cash for the cart horse owners was recorded as 80-100 ETB per day. The current study indicated that the cart horse contribution to livelihood of communities is considerable. The working animals deserve better husbandry and veterinary care to sustain their contribution. We suggest a more detailed and systematic study be conducted in the study area to influence policy makers towards better regulation in animal welfare.
\end{abstract}

Keywords: Cart horses, Economic contribution, Gondar, Ethiopia.

\section{INTRODUCTION}

Equines are widely distributed throughout the world. There are about 1.91 million horses, 6.75 million donkeys and over 0.35 million mules in Ethiopia (CSA, 2013). Ethiopia has the largest equine population, probably with the highest density per square kilo meter in the world and it has a total of $6.9 \%$ of the World's and $42.4 \%$ of Africa's equine population (Alemayehu, 2004).

Equines are important animals to the resource-poor communities in both rural and urban areas, providing traction power and transport services like pulling cart, packing and riding, at low cost. In the remote areas of Ethiopia, pack animals offer the only realistic way of obtaining returns from agriculture above mere existence. Moreover, the increasing human population in Ethiopia has resulted in an increase in demands of horses for transport of goods to and from far, remote areas and construction activities (Biffa and Woldemeskel, 2006). The use of equines in door-todoor transport services also provides urban dwellers with the opportunity of income generation Momona Ethiopian Journal of Science (MEJS), V12(1):135-147,2020 @ CNCS, Mekelle University, ISSN:2220-184X Submitted on: 02-05-2017 
(Wilson, 1991; Agajie et al., 2000). The majorities of working equines are owned by individuals who use them as their sole means of income to sustain often large and extended families. In developing nations where 96 per cent of all donkeys and 60 per cent of horses are found (Pritchard et al., 2005; Wilson, 2002), hundreds of millions of impoverished people depend on equines for their livelihoods, from transport of water to attractions for tourists. Up to 20 people can be dependent on each animal for their daily survival (The Brooke, 2007). In addition to their traditional role as pack and riding animals, equines, most notably donkeys as they are cheaper than oxen and more resistant to droughts, are increasingly used for light cultivation tasks, threshing, drawing water and carting (Howe et al., 1997).

Practically, all of the equines kept in Ethiopia are used for transportation of both humans and materials/goods at some point in their lives, and so make a significant contribution to the livelihoods of most of its citizens. Equines have reduced the domestic transport burden of rural people, especially women, and have created employment and income-generation opportunities for many people. Studies have shown that transport constitutes one of the necessary inputs for rural development and has a positive stimulus for growth in food production, poverty alleviation and overall communication (Pearson et al., 1999; Pearson, 2000). The Brooke welfare assessments (The Brooke, 2008) have found that between 90 and 100 percent of working equine animals suffer lameness and foot abnormalities while 80 per cent have eye abnormalities which may contribute to poor physical and mental welfare. These problems are often exacerbated because in many areas people are paid according to how many goods they can carry, making overloading a major problem. Misuse, mistreatment and lack of veterinary care for equines have contributed enormously to early death, majority of which currently have working life expectancy of 4 to 6 years. However, in countries where animal welfare is properly practiced, the life expectancy of equines reaches up to 30 years (Fred and Pascal, 2006). The welfare of working horses in Ethiopia is therefore crucially important, not only for the health and survival of the animals, but also for the livelihoods of those people dependent on them (Pearson and Krecek, 2006; Wilson, 2002). There is little information regarding working equines in northern Ethiopia, for example Gondar. The economic contribution to improved livelihood and poverty reduction of court horses is not studied in Gondar in particular and in Ethiopia in general. The present study was designed to study the economic contribution of carthorses to livelihood of their owners. 


\section{MATERIAL AND METHODS}

\subsection{Study Area}

The study was conducted on selected sites of Gondar town from November 2014 to April 2015, Amhara National Regional State, North Western of Ethiopia. Gondar town is located on $35^{0} 7^{\prime} \mathrm{N}$ and $13^{\circ} 8^{\prime} \mathrm{E}$ and lies at an altitude of 2,200 meter above sea level. It is found $750 \mathrm{~km}$ north of Addis Ababa. The area receives a mean annual rain fall of $1,172 \mathrm{~mm}$ mainly in rainy season with average temperature of $19.7^{0} \mathrm{C}(\mathrm{GARDO}, 2010)$.

During the study period, working horses in the selected sites of the town were randomly selected purposively and included as part of the study. The expected prevalence was assumed to be $50 \%$ since there was no study conducted previously. The sample size was determined using the Thrusfield formula (Thrusfield, 2005). Animals were subjected to physical examination to record their health status. Semi-structured questionnaire was also administered to cart horse owners to determine the economic contribution of horses to livelihood of their owners.

Observational study was conducted to assess the health status and fitness of working horses. Visualization and palpation of a total of 135 horses was done for direct data collection relating to age, body condition score, skin coat, musculoskeletal problem, eye and mucus membrane abnormality, dental condition, behavior of the horses using clinical data collection format. Age of the horses was also determined by dentition according to Crane (1997). Body condition scores of the horses were estimated according to NAWC (2005) and the horses' body was scored in the range 1-5. However, for the purpose of data analysis it was categorized in three major categories, poor (BCS1-2), moderate (BCS 3), and good (BCS 4-5). Study animals were also grouped into three for the purpose of data analysis: Those under 5 years as young, those in the range of 6-10 years as adult and those beyond 11 years as old.

For the indirect assessment, questionnaire survey was administered to 200 cart horse owners to find out how much the working horse/s is/are supporting for how many household members. Daily income of each cart horse was documented. Furthermore, work load, husbandry practice, provision of water, and the management system of the cart horse was also documented.

\subsection{Data Analysis}

Data from direct physical examination and questionnaires were entered into a Microsoft Excel Spread sheet and analyzed with statistical package for the social science (SPSS) version $20^{\circledR}$ 
analysis software. Descriptive and analytic statistics were used and multinomial logistic regression and Chi-square test $\left(\chi^{2}\right)$ were computed to see the association of risk factors with that target variables of interest. The $p$-value less than 0.05 were considered significant in all analysis.

\section{RESULT}

In the direct assessment, a total of 135 cart horses were clinically examined for different health problems and behavioral responses. Depression (30.4\%), wound (55.6\%), ecto-parasite (50\%) and dental abnormality (31.9\%) were major health problems encountered in the current study. As indicated in Table 1, behavioral responses, skin coat and dental condition were significantly associated with body condition ( $\mathrm{p}<0.05)$. Horses with good body conditions were more alert $(75 \%)$ followed by (58.3\%) depressed in poor body condition horses. Poor body condition horses had rough skin coat $(41.7 \%)$. Wound $(p>0.857)$ and musculoskeletal problems $(p>0.501)$ had no significant association with body condition.

Table 1. Proportion of health status versus body condition of the cart horses.

\begin{tabular}{|c|c|c|c|c|c|c|}
\hline \multirow[t]{2}{*}{ Variable } & \multirow[t]{2}{*}{ Status } & \multicolumn{3}{|c|}{ Body Condition } & \multirow{2}{*}{$\begin{array}{l}\text { Total } \\
N=135\end{array}$} & \multirow[t]{2}{*}{ Pvalue } \\
\hline & & $\begin{array}{l}\text { Poor } \\
(n=35)\end{array}$ & $\begin{array}{l}\text { Moderate } \\
(n=75)\end{array}$ & $\begin{array}{l}\text { Good } \\
(n=24)\end{array}$ & & \\
\hline \multirow{4}{*}{$\begin{array}{l}\text { Behavioral } \\
\text { response }\end{array}$} & Depressed & $21(58.3 \%)$ & $19(25.3 \%)$ & $1(4.2 \%)$ & $41(30.4 \%)$ & 0.000 \\
\hline & Alert & $10(27.7 \%)$ & $48(64 \%)$ & $18(75 \%)$ & $76(56.3 \%)$ & \\
\hline & Accompanied & $1(2.7 \%)$ & $5(6.6 \%)$ & $2(8.3 \%)$ & $8(6.9 \%)$ & \\
\hline & Hypersthetic & $4(11.1 \%)$ & $3(4 \%)$ & $3(12.5 \%)$ & $10(7.4 \%)$ & \\
\hline \multirow[t]{5}{*}{ Skin coat } & Rough & $15(41.7 \%)$ & $19(25.3 \%)$ & $8(33.3 \%)$ & $42(31.1 \%)$ & 0.036 \\
\hline & Dehydrated & $6(16.7 \%)$ & $6(8 \%)$ & $0(0 \%)$ & $12(8.8 \%)$ & \\
\hline & Alopecia & $5(13.9 \%)$ & $10(13.3 \%)$ & $1(4.2 \%)$ & $16(11.8 \%)$ & \\
\hline & Branded & $2(5.6 \%)$ & $2(2.7 \%)$ & $1(4.2 \%)$ & $5(3.7 \%)$ & \\
\hline & Scaling & $2(5.6 \%)$ & $1(1.3 \%)$ & $0(0 \%)$ & $3(2.2 \%)$ & \\
\hline Dental condition & Abnormal & $18(50 \%)$ & $20(26.7 \%)$ & $5(20.8 \%)$ & $43(31.9 \%)$ & 0.024 \\
\hline Ecto-parasite & Present & $25(69.4 \%)$ & $33(44 \%)$ & $10(41.6 \%)$ & $68(50.3 \%)$ & 0.063 \\
\hline \multirow[t]{4}{*}{$\begin{array}{l}\text { Musculoskeletal } \\
\text { problem }\end{array}$} & $\begin{array}{ll}\begin{array}{l}\text { Hoof } \\
\text { growth }\end{array} & \text { over } \\
\end{array}$ & $9(25 \%)$ & $22(29.3 \%)$ & $3(12.5 \%)$ & $34(25.2 \%)$ & 0.501 \\
\hline & Abnormal gait & $7(19.4 \%)$ & $14(18.7 \%)$ & $5(20.8 \%)$ & $26(19.3 \%)$ & \\
\hline & Joint problem & $3(8.3 \%)$ & $4(5.3 \%)$ & $1(4.2 \%)$ & $8(5.93 \%)$ & \\
\hline & Lameness & $5(13.9 \%)$ & $10(13.3 \%)$ & $1(4.2 \%)$ & $16(11.9 \%)$ & \\
\hline Wound & Present & $23(63.9 \%)$ & $40(53.3 \%)$ & $12(50 \%)$ & $75(55.6 \%)$ & 0.857 \\
\hline \multirow[t]{2}{*}{ Mucus membrane } & Pale & $10(28.6 \%)$ & $20(26.7 \%)$ & $8(33.3 \%)$ & $38(28.1 \%)$ & 0.340 \\
\hline & Congested & $3(8.6 \%)$ & $2(2.7 \%)$ & $3(12.5 \%)$ & $8(5.9 \%)$ & \\
\hline
\end{tabular}


As shown in table 2, behavioral response, skin coat, dental abnormality and mucus membrane were significantly associated with age $(\mathrm{p}<0.05)$. Horses with under the age of 5 years were more alert (76.9\%), 6-10 years of age were more depressed (40.6\%) and >11 years of age were hypersthetic (difficult to handle) (10.5\%). The study also demonstrated that high occurrence of dental abnormality in horses of $>11$ years of age. High occurrence of pale mucus membrane was recorded in horses of $>11$ years $(36.8 \%)$ and followed by $6-10$ years of age $(32.7 \%)$.

Table 2. Description of health challenges versus age of the cart horses.

\begin{tabular}{|c|c|c|c|c|c|c|}
\hline \multirow[t]{2}{*}{ Category } & \multirow[t]{2}{*}{ Health status } & \multicolumn{3}{|c|}{ Age } & \multirow{2}{*}{$\begin{array}{l}\text { Total } \\
N=135\end{array}$} & \multirow[t]{2}{*}{ Pvalue } \\
\hline & & $(n=52)$ & $\begin{array}{l}6-10 \text { years } \\
(n=64)\end{array}$ & $\begin{array}{l}>11 \text { years } \\
(n=19)\end{array}$ & & \\
\hline \multirow{4}{*}{$\begin{array}{l}\text { Behavioral } \\
\text { response }\end{array}$} & Depressed & $8(15.4 \%)$ & $26(40.6 \%)$ & $7(36.9 \%)$ & $41(30.4 \%)$ & 0.007 \\
\hline & Alert & $40(76.9 \%)$ & $29(45.3 \%)$ & $7(36.9 \%)$ & $76(56.3 \%)$ & \\
\hline & Accompanied & $1(1.9 \%)$ & $4(6.3 \%)$ & $3(15.8 \%)$ & $8(5.9 \%)$ & \\
\hline & Hypersthetic & $3(5.8 \%)$ & $5(7.8 \%)$ & $2(10.5 \%)$ & $10(7.4 \%)$ & \\
\hline \multirow[t]{5}{*}{ Skin coat } & Rough & $11(21.2 \%)$ & $27(42.2 \%)$ & $4(21.1 \%)$ & $42(31.1 \%)$ & 0.004 \\
\hline & Dehydrated & $4(7.7 \%)$ & $3(4.7 \%)$ & $5(26.3 \%)$ & $12(8.9 \%)$ & \\
\hline & Alopecia & $5(9.6 \%)$ & $8(12.5 \%)$ & $3(15.8 \%)$ & $16(11.9 \%)$ & \\
\hline & Branded & $1(1.9 \%)$ & $2(3.1 \%)$ & $2(10.5 \%)$ & $5(3.7 \%)$ & \\
\hline & Scaling & $0(0 \%)$ & $3(4.7 \%)$ & $0(0 \%)$ & $3(2.2 \%)$ & \\
\hline Dental abnormality & Present & $11(21.2 \%)$ & $20(31.3 \%)$ & $12(63.2 \%)$ & $43(31.9 \%)$ & 0.003 \\
\hline Ecto-parasite & Present & $20(38.5 \%)$ & $38(59.4 \%)$ & $10(52.6 \%)$ & $68(50.4 \%)$ & 0.185 \\
\hline \multirow[t]{4}{*}{$\begin{array}{l}\text { Musculoskeletal } \\
\text { abnormality }\end{array}$} & $\begin{array}{l}\text { Hoof over } \\
\text { growth }\end{array}$ & $10(19.2 \%)$ & $16(37.5 \%)$ & $8(42.1 \%)$ & $34(25.2 \%)$ & 0.350 \\
\hline & Abnormal gait & $8(15.3 \%)$ & $13(20.3 \%)$ & $5(26.3 \%)$ & $26(19.3 \%)$ & \\
\hline & Joint problem & $2(3.8 \%)$ & $5(7.8 \%)$ & $1(5.3 \%)$ & $8(5.9 \%)$ & \\
\hline & Lameness & $8(15.3 \%)$ & $6(9.4 \%)$ & $2(10.5 \%)$ & $16(11.9 \%)$ & \\
\hline Wound & Present & $25(48.1 \%)$ & $39(60.9 \%)$ & $11(57.9 \%)$ & $75(55.6 \%)$ & 0.730 \\
\hline \multirow{2}{*}{$\begin{array}{l}\text { Mucous } \\
\text { membrane }\end{array}$} & Pale & $17(32.7 \%)$ & $14(21.9 \%)$ & $7(36.8 \%)$ & & 0.007 \\
\hline & Congested & $0(0 \%)$ & $4(6.3 \%)$ & $4(21.1 \%)$ & & \\
\hline
\end{tabular}

High occurrence of wound was found on the back sore (20\%) and followed by chest sore $(19.3 \%)$, tail sore $(11.9 \%)$, and thigh sore $(4.4 \%)$, respectively (Table 3$)$.

Table 3. Description of wound on different anatomical locations and its frequency.

\begin{tabular}{|lcc|}
\hline Wound & Frequency in number & Percentage (\%) \\
\hline Back sore & 27 & $20 \%$ \\
\hline Chest sore & 26 & $19.3 \%$ \\
\hline Tail sore & 16 & $11.9 \%$ \\
\hline Thigh sore & 6 & $4.4 \%$ \\
\hline
\end{tabular}


Table 4. Demographic characteristics of the respondent.

\begin{tabular}{|llll|}
\hline Parameter & Category & $\begin{array}{l}\text { Frequency } \\
(\mathbf{N = 2 0 0})\end{array}$ & $\begin{array}{l}\text { Percentage } \\
\text { respondent } \\
(\mathbf{N = 2 0 0 )}\end{array}$ \\
\hline Age of the owner & $<25$ years & 24 & $12.0 \%$ \\
\cline { 2 - 4 } & 25-45 years & 140 & $70.0 \%$ \\
\cline { 2 - 4 } & $>45$ years & 36 & $48.0 \%$ \\
\hline Education level & Illiterate & 66 & $33.0 \%$ \\
\cline { 2 - 4 } & Elementary & 96 & $48.0 \%$ \\
\cline { 2 - 4 } & $\begin{array}{l}\text { High school } \\
\text { completed }\end{array}$ & $19.0 \%$ \\
\hline
\end{tabular}

Table 5. Number of horses and family size.

\begin{tabular}{|c|c|c|c|}
\hline Economic activity & Category & $\begin{array}{l}\text { Frequency } \\
(N=200)\end{array}$ & $\begin{array}{l}\text { Percentage } \\
\text { respondents } \\
(N=200)\end{array}$ \\
\hline \multirow[t]{4}{*}{ Number of horses } & 1 horse & 55 & $27.5 \%$ \\
\hline & 2 horses & 89 & $44.5 \%$ \\
\hline & 3 horses & 33 & $16.5 \%$ \\
\hline & $>3$ horses & 23 & $11.5 \%$ \\
\hline \multirow{4}{*}{$\begin{array}{l}\text { Number } \\
\text { families }\end{array}$} & No family & 12 & $6.0 \%$ \\
\hline & $1-3$ & 90 & $45.0 \%$ \\
\hline & $4-6$ & 72 & $36.0 \%$ \\
\hline & $>6$ & 26 & $13.0 \%$ \\
\hline \multirow{4}{*}{$\begin{array}{l}\text { Number of kids } \\
\text { at school }\end{array}$} & No kids & 28 & $14.0 \%$ \\
\hline & $1-2$ & 121 & $60.5 \%$ \\
\hline & $3-4$ & 50 & $25.0 \%$ \\
\hline & $>4$ & 1 & $0.5 \%$ \\
\hline \multirow{4}{*}{$\begin{array}{l}\text { Daily income } \\
\text { from the cart horse }\end{array}$} & $50-80$ birr & 51 & $25.5 \%$ \\
\hline & $80-100$ & 67 & $33.5 \%$ \\
\hline & $100-120$ & 52 & $26.0 \%$ \\
\hline & $>120$ & 30 & $15.0 \%$ \\
\hline
\end{tabular}

Among the 200 cart horse owners, the $70 \%$ of the respondents were found in the age group of 25-45 years. As to the educational status of cart horse owners, $48 \%$ of them were literate and $33 \%$ illiterate (Table 4). Out of the 200 interviewed cart horse owners, $44.5 \%$ had two horses. $33.5 \%$ of the respondents had 80-100 birr daily. Moreover, the daily income is used as livelihood of the families. The majority of the respondents have 1-3 family members (45\%) and 1-2 number of kids $(60.5 \%)$ (Table 5). 
Among the 200 horse owners interviewed, 32\% of them used horses for cart purposes and $68 \%$ for pack purposes. Majority of the respondents (42\%) were using their horses for transportation for more than 8 hours a day and $63 \%$ for 5-6 days per week. $34 \%$ of the respondent used their horses to transport a load of $500-700 \mathrm{~kg}$ at a time, $32 \%$ loads $300-500 \mathrm{~kg}$, $17 \%$ loads $700-800 \mathrm{~kg}, 14 \%$ loads $>800$. The majority of the respondents $(39.5 \%)$ provide $3-5$ hours rest per day for their horses, whereas, $31 \%$ and $29.5 \%$ of the respondents provided less than 3 hours and more than 5 hours per day respectively (Table 6).

Table 6. Working nature of horses.

\begin{tabular}{|l|l|l|l|}
\hline Working activity & Category & Frequency & Percentage \\
\hline \multirow{5}{*}{ Weight loaded in killo grams } & $300-500 \mathrm{~kg}$ & 64 & $32.0 \%$ \\
\cline { 2 - 4 } & $500-700 \mathrm{~kg}$ & 74 & $34.0 \%$ \\
\cline { 2 - 4 } & $700-800 \mathrm{~kg}$ & 34 & $17.0 \%$ \\
\cline { 2 - 4 } & $>800 \mathrm{~kg}$ & 28 & $14.0 \%$ \\
\hline Days working in a week & $<5$ days & 2 & $1.0 \%$ \\
\cline { 2 - 4 } & $5-6$ days & 126 & $63.0 \%$ \\
\cline { 2 - 4 } & 7 days & 72 & $36.0 \%$ \\
\hline Working time in a day & $5-6$ hours & 63 & $31.5 \%$ \\
\cline { 2 - 4 } & $7-8$ hours & 53 & $26.5 \%$ \\
\cline { 2 - 4 } & $>8$ hours & 84 & $42.0 \%$ \\
\hline Resting time in a day & $<3$ hours & 62 & $31.0 \%$ \\
\cline { 2 - 4 } & $3-5$ hours & 79 & $39.5 \%$ \\
\cline { 2 - 4 } & $>5$ hours & 59 & $29.5 \%$ \\
\hline Working type & Pack & 64 & $32 \%$ \\
\cline { 2 - 4 } & Cart & 136 & $68 \%$ \\
\hline
\end{tabular}

Feed consisted of hay, straw, wheat bran and oil seed cake. Most of the horses fed straw $(52 \%)$ type of feed. The majority of respondents fed their equines at different frequencies. Among 200 horse owners majority $(43 \%)$ of the respondents provided feed three times per day, while $37 \%$ and $19.5 \%$ of the respondents feed their horses ad libitum per day and twice per day, respectively, while $52.5 \%$ and $36.5 \%$ of the interviewed provided water three times and twice per day to their horses, respectively. Furthermore, $53.5 \%$ of the respondents used blanket as padding materials. $85.5 \%$ of respondents kept their horses in shelter at night (Table 7). 
Table 7. Husbandry practice.

\begin{tabular}{|c|c|c|c|}
\hline Husbandry activity & Category & Frequency & Percentage \\
\hline \multirow[t]{4}{*}{ Type of feeding given } & Grain & 19 & $9.5 \%$ \\
\hline & Straw & 104 & $52.0 \%$ \\
\hline & Wheat bran & 66 & $33.0 \%$ \\
\hline & Oil seed cake & 11 & $5.5 \%$ \\
\hline \multirow{4}{*}{$\begin{array}{l}\text { Frequency of feed } \\
\text { provided in a day }\end{array}$} & Once & 1 & $0.5 \%$ \\
\hline & Twice & 39 & $19.5 \%$ \\
\hline & 3times & 86 & $43.0 \%$ \\
\hline & Adlibitum & 74 & $37.0 \%$ \\
\hline \multirow{4}{*}{$\begin{array}{l}\text { Frequency of water } \\
\text { provided in a day }\end{array}$} & Once & 0 & $0.0 \%$ \\
\hline & Twice & 73 & $36.5 \%$ \\
\hline & 3times & 105 & $52.5 \%$ \\
\hline & Adlibitum & 22 & $11.0 \%$ \\
\hline \multirow{3}{*}{$\begin{array}{l}\text { Kind of padding } \\
\text { materials used }\end{array}$} & Blanket & 107 & $53.5 \%$ \\
\hline & Clothes & 69 & $34.5 \%$ \\
\hline & $\begin{array}{l}\text { Straw made } \\
\text { padding }\end{array}$ & 24 & $12.0 \%$ \\
\hline \multirow{3}{*}{$\begin{array}{l}\text { Places to stay in at } \\
\text { night }\end{array}$} & within a shelter & 171 & $85.5 \%$ \\
\hline & $\begin{array}{l}\text { Loose in a } \\
\text { village }\end{array}$ & 1 & $0.5 \%$ \\
\hline & $\begin{array}{l}\text { Loose in a } \\
\text { compound }\end{array}$ & 28 & $14.0 \%$ \\
\hline
\end{tabular}

\section{DISCUSSION}

In Gondar town, cart horses are kept mainly to transport people and goods in order to assure their owners' daily income. The economic contributions of horses were associated with the livelihood of owners. In addition to this, the horses contributed to the sustainable livelihood of families who are economically disadvantaged thereby to the growth of the overall economy. In general, 68\% and $32 \%$ working horses were involved in pack and cart type of use, respectively.

The result of direct welfare assessment revealed different health and welfare constraints. The result indicated that behavioral responses, skin coat and dental condition were significantly associated with body condition ( $\mathrm{p}<0.05$ ). Horses with poor body condition were more depressed (58.3\%) and good body conditions were more alert (75\%). This could be due to lack of attention given to the animals, overloading and long working hours without providing enough rest. This result was in agreement with Bulitta et al. (2012); and Biswas et al. (2013) who reported that majority of the animals (82\%) were alert but $18 \%$ of them were in depressed state. The current 
result also indicated that wound $(\mathrm{p}>0.8)$ and musculoskeletal problems $(\mathrm{p}>0.5)$ had no significant association with body condition. There was no statistically significant association between wound $(\mathrm{P}>0.8)$ and body condition. All category of body condition of horses were at the risk of developing wound. This might be due to improper harness and padding materials that cause excessive rubbing of the body of the horses and travelling long distances without enough rest and deprived of water and feed.

Among the 200 horse owners interviewed, 32\% of them used their horses for cart purposes and $68 \%$ for pack purposes, which slightly differs from the study reported by Mekuria et al. (2013) where they concluded that $100 \%$ of horses used for cart purposes in southern Ethiopia. As the city of Gondar is one of the tourist attractions Ethiopia, the variation in the use of working equines at country level may not be surprising. Majority of the respondents (42\%) were using their horses for transportation for more than 8 hours per day and 63\% for 5-6 days per week. Of the respondents, $34 \%$ of them used their horses to transport loads of $500-700 \mathrm{~kg}$ but $14 \%$ of respondents load their horses $>800 \mathrm{~kg}$. This is because people tend to earn more money than giving attention to their working animals including to the load, they just maintain whatever they get just once to avoid another journey. In addition, they are also completely dependent on the income they generate per day for their livelihood by the cart horses. The majority of the respondents, $39.5 \%$ of them, provide 3-5 hours rest per day for their horses, whereas, $31 \%$ and $29.5 \%$ of the respondents provided less than 3 hours and more than 5 hours per day respectively (Table 3 ).

Although, the feed available in Gondar town commonly consists of hay, straw, wheat bran and oil seed cake, most of the horses are fed on straw (52\%) type of feed. The present study showed that the majority of respondents feed their horses at different frequencies. Among the 200 horse owners, the majority (43\%) feed their horses three times per day, while $37 \%$ and $19.5 \%$ of the respondents feed ad libitum per day. This is the case whenever they did not get anything to be done, and twice per day, respectively. Out of the 200 interviewed cart horse owners, 52.5\% provided water three times per day to their horses and $36.5 \%$ of them only twice. This result is in agreement with the study reported by Mekuria et al. (2013). The finding of this study also demonstrated that $53.5 \%$ of the respondents used blanket as padding materials. While $85.5 \%$ of the respondents keep their animals within a shelter at night (Table 4). 
As indicated in table 3, high occurrence of wound was found on the back sore (20\%) followed by chest sore (19.3\%), tail sore (11.9\%) and thigh sore (4.4\%). This could be due to overloading, extended working hours and improper padding and harnessing materials. This study is in line with Pearson et al. (2000); and Helen (2001) who concluded that wooden or iron made saddles are constantly put on the back/shoulder and are strongly tied to the body by plastic rope, which causes persistent irritation and injuries. In most cases, harnesses were made of car tire strips, which cut into the skin of the horse and form large open wounds. Out of the 200 respondents of cart horse owners, $44.5 \%$ of them owned two horses (Table 2). The current price of a horse in the study area is about 5000 ETB. This is additional challenge to people to own more horses and ease the burden of their animals. The income of cart horse owners (33.5\%) generate on average 100250 ETB per day. Moreover, the daily income is used as means of livelihood of the families. The majority of the respondents have 1-3 family members (45\%) and 1-2 number of kids (60.5\%). Due to the family size, the daily incomes (100-250 ETB) was not enough to fulfill the demand of the families and thus forced to work longer hours with overloading of their horses. This leads to compromising the animal welfare and economic benefits of working equines while appreciating their contribution in poverty alleviation and sustaining livelihoods of resource poor families. It is concluded that equines are crucial to sources-poor families. It is recommended the welfare of the working horses needs urgent attention.

\section{ACKNOWLEDGEMENT}

The authors would like to acknowledge the cart horse owners of Gonder for providing us information and support required for this research.

\section{CONFLICTS OF INTEREST}

The authors would like to declare that there is no conflict of interest

\section{REFERENCE}

Agajie, T., Tamirat, D., Pearson, A \& Temesgen, T. 2000. Socio-economic circumstances of donkeys use and management in the rural and urban areas of central parts of Ethiopia. 
Proceedings of the Workshop on Promoting the Peri-Urban Livelihood Through Better Donkey Welfare. Debre-zeit, Ethiopia, pp16-28.

Alemayehu, L. 2004. Case Studies on Reproductive Activity of Equines in Relation to Environmental Factors in Central Ethiopia. PhD thesis, German Edition, University of Berlin, Humboldt, ISBN-10: 3833413972, 158p.

Biffa, D \& Woldemeskel, M. 2006. Causes and factors associated with occurrence of external injuries in working equines in Ethiopia. International Journal of Applied Research in Veterinary Medicine, 4(1): 7-12.

Bulitta, F., Gebresenbet, G \& Bosona, T. 2012. Animal Handling during Supply for Marketing and Operations at an Abattoir in Developing Country: The case of 19 Gudar market and Ambo Abattoir, Ethiopia. Journal of Service Science and Management, 5(1): 59-68 (DOI: 10.4236/jssm.2012.51008).

Biswas, P., Dutt, T., Patel, M., Kamal, R., Bharti, P.K \& Sahu, S. 2013. Assessment of pack animal welfare in and around Bareilly city of India. Vet. World, 6(6): 332-336 (doi:10.5455/vetworld.2013.332-336).

Crane, M, 1997. Medical treatment. In: E.D.Svenden (ed.), The professional hand book of the donkey, $3^{\text {rd }}$ edition, Whittet book limited London, United Kingdom. pp 9-25.

CSA (Central Statistical Agency) 2013. Federal Democratic Republic of Ethiopia Agriculture sample survey. Report on livestock and livestock characteristics.

Demelash, B \& Moges, W. 2006. Causes and influencing factors of external injuries in a working population of horses and donkeys in southern Ethiopia. Int. J. Appl. Res. Vet. Med., 4(1): 7 - 13

FAO, (Food and Agriculture Origination) 2008. Capacity building to implement good animal practices. Report of the FAO expert. Meeting FAO. Headquarters (Rome), 30 September -3 October, 2008, FAO of the United Nations, Rome, Italy.

Fred, O \& Pascal, K. 2006. Extension approaches to improving the welfare of working equines. Kenya Network for Dissemiation of Agricultural Technologies (KENDAT), Nairobi, 28p.

GARDO. 2010. Gondar Agriculture and Rural Development Office. Annual Report of 2009. 
Helen, B. 2001. The gharry horses of Gonder. Draught animal news, Centre for Tropical Veterinary Medicine, University of Edinburg, Scotland, 35: 23-24.

Howe, J \& Garba, R. 1997. Farm-level transport and animal dependency in Kaffecho Zone, Ethiopia. In: Proceedings of the Animal Transport and Network of Eastern and Southern Africa (ATNESA) Workshop on "Improving Donkey Utilization and Management", Debre-Zeit, Ethiopia.

Mekuria, S., Mulachew, M \& Abebe, R. 2013. Management practices and welfare problems encountered on working equids in Hawassa town, Southern Ethiopia. Journal of veterinery medicine and animal health, 5(9): 243-250.

NAWC (National Animal Welfare Council). 2005. Equine industry welfare guideline compendium for horse ponies and donkey. $2^{\text {nd }}$ edition, Body Condition Scoring for horse and donkey, pp. 82-95.

Pearson, R. A. 2000. Use and Management of Donkeys by Poor Societies in Peri-urban Areas of Ethiopia. In: D. G. Smith, T. Agajie and L. More (eds.), Alleviating Poverty in Peri-Urban Ethiopia by Improving the Health, Welfare and Management of Donkeys. CTVM, Edinburgh, pp. 2-5.

Pearson, R.A \& Krecek, R.C. 2006. Delivery of health and husbandry improvements to working animals in Africa. Tropical Animal Health and Production, 38: 93-101.

Pearson, R. A., Zerbini, E \& Lawrence, P. R. 1999. Recent Advances in Research on Draught Animals. Animal Science, 68: 1-17.

Popescu, S., Diugan, E. A \& Spinu, M. 2014. The interrelations of good welfare indicators assessed in working horses and their relationships with the type of work. Res. Vet. Sci., 96(2): 40614 (doi: 10.1016/j.rvsc.2013.12.014).

Pritchard, J.C., Lindberg, A.C., Main, D.C \& Whay, H.R. 2005. Assessment of the welfare of working horses, mules and donkeys, using health and behaviour parameters. Prev Vet Med., 69(3-4): 265-283.

The Brooke. 2007. Bearing a Heavy Burden. Available online. http://www.fao.org/fileadmin/user_upload/animalwelfare/BROOKEReport.pdf (Accessed 01/ 06/ 2015) using Health and Behaviour Parameters. 
The Brooke, 2008. Donkeys, horses and mules - their contribution to people's livelihoods in Ethiopia. Available at https://www.thebrooke.org/sites/default/files/Advocacy-andpolicy/Ethiopia-livelihoods-2020-01.pdf

Thrusfiled, M. 2005. Veterinary epidemiology. $3^{\text {rd }}$ edition, ISBN: 978-1-405-15627-1, Blackwell Publishing, 626p.

Wilson, R.T. 1991. Equines in Ethiopia. In: Fielding D, Pearson RA (eds.), Donkeys, Mules and Horses in Tropical Agricultural Development. Proceedings of Colloquium held 3-6 September, 1990. Centre for Tropical Veterinary Medicine: University of Edinburgh, Scotland, pp 33-47.

Wilson, R.T. 2002. Specific welfare problems associated with working horses. In: N. Waran (ed..), The welfare of horses. Animal Welfare, Volume 1, Springer, pp203-218 (DOI: 10.1007/978-0-306-48215-1_9). 